\title{
Workload: a comparison between the online and observational methods
}

\author{
Carga horária de trabalho: comparação dos métodos observacional e on-line \\ Carga horaria de trabajo: comparación de los métodos observacionales y online
}

\section{Rute Merlo Somensi', Rita Catalina Aquino Caregnato', Gustavo Henrique Cervi', Cecilia Dias Flores'}

' Fundação Universidade Federal de Ciências da Saúde de Porto Alegre. Porto Alegre, Rio Grande do Sul, Brazil.

\author{
How to cite this article:
}

Somensi RM, Caregnato RCA, Cervi GH, Flores CD. Workload: a comparison between the online and observational methods. Rev Bras Enferm [Internet]. 2018;71(4):1850-7. DOI: http://dx.doi.org/10.1590/0034-7167-2017-0313

Submission: 05-17-2017 Approval: 07-16-2017

\begin{abstract}
Objective: To measure nursing Workload (WL) of nurses who work in the Inpatient Unit, as recommended by the Nursing Interventions Classification (NIC), comparing observational and online methods to propose supervision strategies for academic professionals. Method: Quantitative, descriptive, observational study performed in a Clinical/Surgical Hospital Unit. 30 direct and indirect activities. Data collected in observational and online records. Statistical analysis: SPSS 18.0 software, percentage frequencies and associated times between groups by Fisher's Exact test, 95\% confidence interval, significance level 5\%. Results: Comparing the activities performed with the NIC time: from the direct 16, five observational and five online, were out of range, with no significant difference between frequencies $(\mathrm{P}=0.427)$. Of the 14 indirect, only in the observational, two were out of the range, without significant difference $(P=0.486)$. Conclusion: Both methods measure WL; the online method developed accompanies activities performed in real time.
\end{abstract}

Descriptors: Workload; Personnel Dimensioning; Nurses; Quality of Health Care; Resource Management of the Health Care Team.

\section{RESUMO}

Objetivo: Mensurar a Carga de Trabalho (CT) dos enfermeiros que atuam em Unidade de Internação, conforme preconiza a Nursing Interventions Classification (NIC), comparando os métodos observacional e on-line, para propor estratégias de supervisão dos profissionais eacadêmicos. Método: Estudo observacional descritivo quantitativo realizado em uma Unidade de Internação Clínica/ Cirúrgica. 30 atividades diretas e indiretas. Dados levantados em registros observacional e on-line. Análise estatística: Software SPSS 18.0, frequências percentuais e tempos associadas entre grupos pelo teste Exato de Fisher, intervalo de confiança 95\%, nível de significância 5\%. Resultados: Comparando as atividades executadas com o tempo preconizado pela NIC: das 16 diretas, cinco no observacional e cinco no on-line, estavam fora do intervalo, sem diferença significativa entre frequências $(P=0,427)$. Das 14 indiretas, apenas no observacional, duas estavam fora do intervalo, sem diferença significativa $(\mathrm{P}=0,486)$. Conclusão: Ambos os métodos servem para medir CT; o método on-line desenvolvido acompanha atividades executadas em tempo real.

Descritores: Carga de Trabalho; Dimensionamento de Pessoal; Enfermeiros; Qualidade da Assistência à Saúde; Gestão de Recursos da Equipe de Assistência à Saúde.

\section{RESUMEN}

Objetivo: Medir la carga de trabajo (CT) de los enfermeros que actúan en Unidad de Internación, según preconiza la Nursing Interventions Classification (NIC), comparando los métodos observacional y online, para proponer estrategias de supervisión de los profesionales y académicos. Método: Estudio observacional descriptivo cuantitativo realizado en una Unidad de Internación Clínica/Quirúrgica. 30 actividades directas e indirectas. Datos recogidos en registros observacionales y en línea. Análisis estadístico: Software SPSS 18.0, frecuencias porcentuales y tiempos asociados entre grupos por la prueba Exacto de Fisher, intervalo de confianza 95\%, nivel de significancia 5\%. Resultados: Comparando las actividades realizadas con el tiempo preconizado por la NIC: de las 16 directas, cinco en el observacional y cinco en el on-line, estaban fuera del intervalo, sin diferencia significativa entre frecuencias $(P=0,427)$. De las 14 indirectas, sólo en el observacional, dos estaban fuera 
del intervalo, sin diferencia significativa $(\mathrm{P}=0,486)$. Conclusión: Ambos métodos sirven para medir $\mathrm{CT}$; el método online desarrollado acompaña actividades ejecutadas en tiempo real.

Descriptores: Carga de Trabajo; Dimensionamiento de Personal; Enfermeros; Calidad de la Asistencia Sanitaria; Gestión de Recursos del Equipo de Asistencia Sanitaria.

\section{CORRESPONDING AUTHOR Rute Merlo Somensi E-mail: rute@santacasa.tche.br}

\section{INTRODUCTION}

The nursing Workload (WL) is constituted by the time spent to perform the activities related to direct or indirect care in the care of the patient under their responsibility, being influenced by the degree of dependence of the patients, complexity of the diseases, professional profile and characteristics of the institution $^{(1)}$. The WL has different approaches in work relations, since it is related to the physical, chemical, biological, mechanical, physiological and psychic conditions that the professional is inserted $^{(2)}$. Under another approach, the WL is understood as staffing, while quantity of work ${ }^{(2)}$.

The complexity of the care provided to patients makes it difficult to measure the WL of activities performed by nurses through the average time in health services ${ }^{(3)}$. The observational method has been the most adopted to know the activities performed by nurses and the average time to the care be performed $^{(4)}$. Emphasis is placed on risk factors for the errors occurrence: the work overload and the inadequacy of the number of nurses ${ }^{(5)}$. Negative influence on the health of the worker is added, particularly when the nursing team is under-sided or in deviance, leading to dissatisfaction, physical and psychic overload, absenteeism and stress ${ }^{(6)}$.

The Nursing Interventions Classification (NIC) defines an intervention performed by the nurse as "any treatment based on the judgment and clinical knowledge that a nurse performs to improve patient outcomes" ${ }^{\prime(7)}$. These assistance interventions are divided by the NIC as direct or indirect, the direct ones being actions of "handshaking" and direct orientations to the care of the patient; and the indirect ones, actions carried out by the nurses, away from the patient, such as supervision of the care and collaboration environment ${ }^{(7)}$. The NIC is a standardized and universal language, so it can be used as a reference for the calculation of the WL, since it establishes average of time spent by the nurse to perform each direct and indirect activity.

Digital technologies such as mobile devices, Personal Digital Assistant (PDAs), notebooks, tablets and even the latest generations of smartphones, for example, can be used by nurses to assist in measuring times, learning about activities, planning, organizing, monitoring and evaluating the processes that involve care $^{(8)}$. These devices may allow managers and teachers to monitor the activities of nurses and academics, enabling the monitoring, evaluation and intervention related to the $\mathrm{WL}$ of the team, aiming to offer assistance with quality and safety.

This study used two methods that make it possible to measure the activities performed by nurses working in a Clinical/Surgical Hospitalization Unit, considering the times to perform the direct and indirect activities, as recommended by the NIC. It was outlined as research problems to investigate: a) What are the private activities performed by nurses working in a clinical and surgical hospitalization unit?; b) Are the activities carried out by Brazilian nurses working in a Clinical/Surgical Hospitalization Unit in accordance with the Nursing Interventions Classification $(\mathrm{NIC})$ ? c) What is the time spent in the execution of each activity performed by the nurse in the care in the Internment Unit?; d) Can observational and online methods allow the evaluation of the nurse's WL?; and e) Is there a difference between observational and online methods for the measurement of the nurse's WL?

\section{OBJECTIVE}

To measure the WL of the nurses who work in an inpatient unit, as recommended by the NIC, comparing the observational and online methods, to propose ways of supervising professionals and academics in the practice of care.

\section{METHODS}

\section{Ethical aspects}

The development of the study met national and international standards of research ethics involving human subjects. This research was approved by the Research Ethics Committee.

\section{Design, place of study and period}

A descriptive observational study with a quantitative approach performed at a 32-bed Clinical/Surgical Inpatient Unit (IU), at a hospital specialized in pulmonology located in Porto Alegre, Rio Grande do Sul State, Brazil. Data were collected by two methods: observational and online. The period of the observational method occurred from March 20 to 30 and the online from May 13 to 23, 2016, totaling 480 hours of records, with 240 hours in each method.

\section{Population and sample, inclusion and exclusion criteria}

The population was constituted by direct and indirect activities performed by the nurses, as recommended in the NIC. In order to select the sample, the following criteria were considered as inclusion criteria: the activities described in the Internal Regulation of the Nursing Service of the institution surveyed, for the exclusion, they are considered outliers, and data recorded from tests and training that were excluded from the sample. The sample consisted of 30 activities measured in minutes and seconds.

\section{Study protocol}

The instruments used for the collection of data were: a) spreadsheet for recording direct and indirect care to the patient and their times; and b) computerized instrument designed by the researcher and developed by the computer team of the research 
group. The variables considered in the observational and online methods were: I) IU management indicators (occupancy rate, mean length of stay and patient/day); II) profile of patients (age, gender and specialties); and III) nurses' profile (time of work experience, number of shifts, workload, and shift time).

The observational method was considered as traditional, because through the non-participant observational technique, the times of each in-situ activity in the 24 hours were measured. However, this method may have the effect of Hawtorne, evidenced from the greater frequency of activities in direct and indirect care. This effect results from an excess in productivity due to the fact that the human being is being observed, differently if it were producing in a natural environment ${ }^{(9)}$. The observational method depends on the observer-only workforce, so it becomes a limited method to be performed in the practice of care. In this sense, this research developed the online method for the purpose of facilitating the recording of the time of the activities.

\section{Analysis of results and statistics}

The online method allows the nurse to access the mobile device and record the information, such as: identification of the professional, identification of the patient, selection of the activity to be developed, beginning and ending, in real time. In this way, the system recorded "who did", "what did", "which patient attended" and "how long the activity lasted", in addition to the date and time that occurred. Time and date information is automatically obtained by the system. The system has two interfaces: one used by the nurse that makes the records available and the other available to the manager/teacher/researcher through reports that aim to follow the activities performed by the nurse in real time.

In the first stage, the observational records of five nurses trained by the hospital's quality department were analyzed through non-participant observation. The activities developed by eight nurses during the workday (morning, afternoon and night) were measured using a digital timer. The data were transcribed in Excel spreadsheet.

To perform the online step from the analysis of observational data, the researcher designed an instrument that enabled the development of a software to capture the information related to the consultations, carried out by the research support group. The technologies used were, in the frontend - HTML5, in the backend - Python language and, for the persistence, the MySQL database was used, in the "tailor made" model. In the online stage, six nurses, also trained by the same sector of the hospital, participated. To analyze the data, the outliers, a term used to refer to distant data from other observations, were identified and excluded from the sample.

Statistical analysis was performed using SPSS 18.0 software, considering frequencies, percentages and associated times between groups by Fisher's Exact test, 95\% confidence interval, 5\% significance level. For the purposes of statistical analysis, the maximum time referred by the NIC for the activity measured was established.

\section{RESULTS}

The results of the variables studied in the observational and online periods, respectively, were extracted from the hospital management system: occupation rate of IU $89.58 \%$ and $95.41 \%$; type of specialty $62 \%$ and $65 \%$ pneumology; mean length of stay in IU 5.68 and 6.5 days; patients/day 301 and 312, which corresponds to the number of patients hospitalized in the study period. The patients' age ranged from 17 to 95 years; gender of patients $55 \%$ female, in both periods; work experience of nurses aged 0.2 to 25 years.

Regarding the classification of patients hospitalized at the level of care in the periods investigated, Perroca ${ }^{(10)}$ considered that: a) in the observational method, in the total of 24 patients classified as severity, 19 had minimal care, four intermediaries and a semi-intensive; and b) in the online, of the 25 patients, 18 had minimal care, four intermediate care and three semi-intensive care.

Table 1 shows the frequencies of direct and indirect activities recorded in observational and online methods. Of the 30 activities categorized in the observational method, a total of 1,901 activities were performed, being 1,499 indirect and 402 direct. In the online method, 2,099 activities were recorded, however, 590 outliers were identified, data recorded from tests and training that were excluded from the sample, resulting in a total of 1,509 , of which 334 were direct activities and 1,175 indirect ones.

Table 1 - Frequency of direct and indirect activities recorded by observational and online methods, Porto Alegre, Rio Grande do Sul State, Brazil, 2016

\begin{tabular}{|c|c|c|c|c|c|}
\hline \multicolumn{3}{|l|}{ Direct activities } & \multicolumn{3}{|c|}{ Indirect activities } \\
\hline Activity & $\begin{array}{c}\text { Observational } \\
\text { n (\%) }\end{array}$ & $\begin{array}{c}\text { Online } \\
\text { n (\%) }\end{array}$ & Activity & $\begin{array}{c}\text { Observational } \\
\text { n (\%) }\end{array}$ & $\begin{array}{c}\text { Online } \\
\text { n (\%) }\end{array}$ \\
\hline High surveillance medications administration & $10(2.49)$ & $15(4.49)$ & Psychotropic count/stock control & $18(1.20)$ & $32(2.72)$ \\
\hline Aspiration of secretions & $2(0.50)$ & $2(0.60)$ & Contact with support areas & $370(24.68)$ & $120(10.21)$ \\
\hline CGG response & $0(00)$ & $2(0.60)$ & Contact with medical staff & $185(12.34)$ & $45(3.83)$ \\
\hline Intercurrent attendance & $27(6.72)$ & $26(7.78)$ & Personnel Dimensioning & $27(1.80)$ & $27(2.30)$ \\
\hline Peripheral vein catheterization & $16(3.98)$ & $2(6.29)$ & SBAR worksheet creation & $26(1.73)$ & $13(1.11)$ \\
\hline Central catheter blood collection & $6(1.49)$ & $4(1.20)$ & Passage on duty & $29(1.93)$ & $40(3.40)$ \\
\hline Water control & $2(0.50)$ & $0(0.0)$ & Application material & 29 (1.93) & $14(1.19)$ \\
\hline Central Catheter/Catheter Care & $19(4.73)$ & $13(3.89)$ & Completion of protocols & $27(1.80)$ & $13(1.11)$ \\
\hline Physical examination & $29(7.21)$ & $5(15.87)$ & Billing Review & $10(0.67)$ & $9(0.77)$ \\
\hline Gasometry & $15(3.73)$ & $8(2.40)$ & Review of medical records & $114(7.61)$ & $35(2.98)$ \\
\hline Chest Drain Maintenance & $28(6.97)$ & $16(4.79)$ & SAE - History & $25(1.67)$ & $22(1.87)$ \\
\hline Guidance to family and patients & $230(57.21)$ & $150(44.91)$ & SAE - Evolution & $296(19.75)$ & $302(25.70)$ \\
\hline Nasogastric tube passage & $5(1.24)$ & $3(0.90)$ & SAE - Prescription & $265(17.68)$ & 384 (32.68) \\
\hline
\end{tabular}




\begin{tabular}{|c|c|c|c|c|c|}
\hline \multicolumn{3}{|l|}{ Direct activities } & \multicolumn{3}{|l|}{ Indirect activities } \\
\hline Activity & $\begin{array}{c}\text { Observational } \\
\text { n (\%) }\end{array}$ & $\begin{array}{l}\text { Online } \\
\text { n (\%) }\end{array}$ & Activity & $\begin{array}{c}\text { Observational } \\
\text { n (\%) }\end{array}$ & $\begin{array}{c}\text { Online } \\
n(\%)\end{array}$ \\
\hline Withdrawal of central intravascular catheters & $8(1.99)$ & $7(2.10)$ & Supervision of technical activities/team management & $78(5.20)$ & $119(10.13)$ \\
\hline Intermittent Vesical Catheterization & $1(0.25)$ & $11(3.29)$ & & & \\
\hline Permanent Vesical Catheterization & $4(1.0)$ & $3(0.90)$ & & & \\
\hline Totals & $402(100)$ & $334(100)$ & Totals & $1499(100)$ & $1175(100)$ \\
\hline
\end{tabular}

Note: SAE - Systematization of Nursing Care; CGG - Cardiac Arrest; SBAR - Situation, Base, scenario, Analysis and Recommendation (tool used for communication among teams).

In Table 2, the activities were analyzed statistically and compared with the longest time referred by the NIC, aiming at different evaluations regarding the nurses' $\mathrm{WL}$. In relation to the direct activities recorded by the observational method, for example, the High surveillance medications administration activity, an average time of 6.11 minutes in the sample was obtained, with $95 \%$ confidence. The average of this activity is a number in the range of 2.78 to 9.44 minutes. As in the NIC, the maximum time value referred to is up to 15 minutes, the average time for this activity is below that recommended by the NIC. For the other activities, it follows the same interpretation.

It is observed that some activities have an interval that exceeds the time referred by the NIC time, evidencing a scenario of using larger times for the activities indicated. Of the 16 direct activities recorded, five observational and five online observations were outside the range of $\mathrm{NIC}$, and there was no statistically significant difference between the two groups $(P=0.427)$. Of the 14 indirect activities in the observational method, two were outside the time referred to by the $\mathrm{NIC}$, and in the online none, and there was no statistically significant difference between the evaluations $(P=0.486)$.

Considering the frequencies of the direct and indirect activities recorded by the observational and online methods (Table 1) and the average time spent in the performance of each activity (Table 2), the percentage of the time spent in the execution of indirect activities was calculated, totalizing $67.5 \%$ in the observational method and $69 \%$ in the online method.

Table 2 - Descriptive table of the average and the 95\% confidence interval for the time of direct and indirect activities by observational and online methods, Porto Alegre, Rio Grande do Sul State, Brazil, 2016

\begin{tabular}{|c|c|c|c|c|c|c|c|}
\hline \multirow{2}{*}{ Direct activities } & \multirow{2}{*}{$\begin{array}{l}\text { NIC } \\
\text { Time }\end{array}$} & \multicolumn{3}{|c|}{ Observational } & \multicolumn{3}{|c|}{ Online } \\
\hline & & Average & $\mathrm{Cl}$ & $95 \%$ & Average & $\mathrm{Cl}$ & $95 \%$ \\
\hline Administration of high vigilance medications & 15 & 6.11 & 2.78 & 9.44 & 8.44 & 5.2 & 11.77 \\
\hline Aspiration of secretions & 15 & 0.38 & 0.38 & 0.38 & 7 & 0 & 52.74 \\
\hline Complications attendance & 30 & 18.1 & 0 & 52.2 & 9.09 & 6.7 & 11.52 \\
\hline Peripheral vein catheterization & 45 & 8.71 & 0 & 57.9 & 11.72 & 7.9 & 15.56 \\
\hline Central catheter blood collection & 15 & 7.36 & 6.19 & 8.53 & 11.44 & 0 & 24.58 \\
\hline Central Catheter/Catheter Care & 45 & 5.22 & 1.17 & 9.28 & 19.21 & 9.8 & 28.6 \\
\hline Chest Drain Maintenance & 15 & 4.97 & 3.51 & 6.43 & 8.88 & 4.8 & 13.02 \\
\hline Nasogastric examination & 15 & 23.59 & 13.8 & 33.4 & 5.01 & 0 & 12.26 \\
\hline Withdrawal of central intravascular catheters & 45 & 9.06 & 5.89 & 12.2 & 9.13 & 6.9 & 11.39 \\
\hline SAE - Physical Examination & 30 & 6.78 & 5.7 & 7.86 & 4.27 & 3.9 & 4.62 \\
\hline Intermittent Vesical Catheterization & 15 & 15.45 & 15.5 & 15.5 & 10.77 & 6.3 & 15.27 \\
\hline Permanent Vesical Catheterization & 15 & 7.19 & 7.19 & 7.19 & 16.92 & 5.8 & 28.06 \\
\hline Gasometry & 15 & 8.87 & 2.72 & 15.03 & 8.91 & 4.8 & 13.02 \\
\hline Water control & 45 & 5.05 & 5.05 & 5.05 & 0 & 0 & 0 \\
\hline PCR response & 45 & 0 & 0 & 0 & 32.72 & 0 & 233.7 \\
\hline Guidance to family and patients & 30 & 3.16 & 3.01 & 3.31 & 4.44 & 3.64 & 5.24 \\
\hline \multicolumn{8}{|l|}{ Indirect activities } \\
\hline Psychotropic Count/Stock Control & 30 & 8.11 & 0 & 18.78 & 12.06 & 7.67 & 16.5 \\
\hline Contact with support areas & 15 & 1.36 & 1.34 & 1.39 & 3.38 & 2.86 & 3.89 \\
\hline Contact with medical staff & 30 & 1.49 & 1.28 & 1.69 & 3 & 2.38 & 3.64 \\
\hline Personnel Dimensioning & 60 & 14.5 & 0 & 58.52 & 1.73 & 1.6 & 1.87 \\
\hline SBAR worksheet creation & 60 & 18.81 & 0 & 219.8 & 36.97 & 25.9 & 48.0 \\
\hline Contact Us & 45 & 29.9 & 11.9 & 47.91 & 28.17 & 24.5 & 31.9 \\
\hline Request for Material - MOU & 30 & 5.39 & 0 & 11.52 & 11.88 & 9.41 & 14.3 \\
\hline Protocol Filling & 60 & 5.41 & 3.18 & 7.65 & 7.59 & 4.06 & 11.1 \\
\hline Billing Review & 60 & 12.41 & 1.6 & 23.22 & 13.2 & 6.86 & 19.5 \\
\hline Review of medical records & 60 & 5.51 & 5.39 & 5.63 & 31.19 & 20.3 & 42.1 \\
\hline SAE - Evolution & 30 & 2.32 & 2.06 & 2.59 & 3.43 & 3.16 & 3.7 \\
\hline SAE - History & 30 & 9.48 & 9.17 & 9.78 & 10.19 & 7.3 & 13.1 \\
\hline SAE - Prescription & 30 & 3.18 & 2.97 & 3.38 & 3.03 & 2.8 & 3.27 \\
\hline Supervision of technical activities/team management & 60 & 2.07 & 1.87 & 2.28 & 7.21 & 2.99 & 11.4 \\
\hline
\end{tabular}

Note: CGG - Cardiac Arrest; SBAR - Situation, Base, scenario, Analysis and Recommendation (tool used for communication among teams); NIC - Nursing Interventions Classification. 
Table 3 - Average and percentage of time spent in the activities performed by nurses in relation to the experience of professionals in the evaluated methods, Porto Alegre, Rio Grande do Sul State, Brazil, 2016

\begin{tabular}{|c|c|c|c|c|c|}
\hline \multicolumn{6}{|c|}{ Observational } \\
\hline $\mathbf{N}$ & Ns & WD (hs/day) & St & $\begin{array}{c}\mathrm{WL} \\
\% \mathrm{WL}=(\mathrm{St} / \mathrm{WD}) * 100\end{array}$ & Twe (years) \\
\hline N1 & 6 & 6 & 4.4 & $73 \%$ & 9 \\
\hline N2 & 1 & 6 & 5.5 & $92 \%$ & 0.2 \\
\hline N3 & 1 & 12 & 8.1 & $68 \%$ & 5 \\
\hline $\mathrm{N} 4$ & 2 & 12 & 8.9 & $74 \%$ & 0.5 \\
\hline N5 & 7 & 6 & 4.4 & $73 \%$ & 13 \\
\hline N6 & 4 & 12 & 8.1 & $68 \%$ & 24 \\
\hline N7 & 4 & 12 & 8.1 & $68 \%$ & 4 \\
\hline N8 & 2 & 12 & 9.0 & $75 \%$ & 7 \\
\hline \multicolumn{6}{|c|}{ Online } \\
\hline N1 & 6 & 6 & 2.3 & $39 \%$ & 9 \\
\hline N1 & 1 & 12 & 5.4 & $45 \%$ & 9 \\
\hline N5 & 7 & 6 & 5.2 & $86 \%$ & 13 \\
\hline N5 & 1 & 12 & 9.5 & $79 \%$ & 13 \\
\hline N6 & 3 & 12 & 8.6 & $72 \%$ & 24 \\
\hline N7 & 6 & 12 & 7.4 & $61 \%$ & 4 \\
\hline N9 & 1 & 12 & 9.8 & $81 \%$ & 0.3 \\
\hline N10 & 2 & 12 & 8.1 & $67 \%$ & 25 \\
\hline
\end{tabular}

Note.-. N: Nurse; Ns: Number of shifts; WD: Working day; St: Shift time; WL: Workload; Twe: time of work experience.

Table 3 presents data on the nurses who performed the activities measured in both methods studied. The variables presented are: N: Nurse; Ns: Number of shifts; WD: Nurses' working day - daytime (six hours) and weekends, holidays and night time of 12 hours; St: Shift time is the nurses productivity and refers to the proportion of time spent in the execution of the exclusive activities to work; WL (workload): it is the time to attend the needs of the patients; Twe: time of work experience. The shaded cells identify the WL of the lowest and highest values analyzed. This table presents the WL of the nurses in the observational and online periods. In the observational, there were 171.64 hours and in the online 161.23 hours. Considering the total of 240 hours in each period, the WL of the team in the ten days was of $71.5 \%$ in the observational and $67.2 \%$ in the online.

\section{DISCUSSION}

A small variation between the percentages of the compared methods is identified in Table 1 . The study by Moreno ${ }^{(11)}$ states that among the most frequent activities performed by nurses in indirect care are: records of nursing processes and administrative activities, and in the direct, communication/orientation to family and patients, corroborating with the findings in this study. Regarding direct care, the greater time of the nurses dedicated to the patients produces better care results with reduction of the index of errors and satisfaction of the team. Few studies measure how nurses distribute their time through activities ${ }^{(4)}$.
The activity "chest drain maintenance" is one of the direct activities most frequently in the observational method, because the study was performed in a hospital specialized in pneumology. It is important to note that the type and prevalence of activities change based on the profile and characteristics of the patients and the hospitalization units, so the situational diagnosis to calculate the WL of the nurses should be considered ${ }^{(3)}$.

In this study, the occupancy rate of the hospitalization unit in the online period was higher than the observational rate in $5.83 \%$. As for the profile of hospitalized patients, clinical and surgical, in the online period, $43 \%$ were surgical, and in the observational period, $26 \%$ were surgical. Patients with a surgical specialty profile require higher WL when compared to patients with clinical diseases ${ }^{(12)}$. When analyzing the classification of patients according to level of care, it is identified that in the online method the unit had a higher WL with two more patients who demanded care at the intermediate and semi-intensive levels.

In the period of application of the on-line method, besides the classification of the patients having been with greater degree of complexity, also presented a greater percentage in the surgical profile, which reveals a higher WL. The "central catheter blood collection" performed by nurses in this research is a restricted procedure due to the high risk of thrombotic occlusion of the catheter, that is, the collection of blood by this route is recommended for the diagnosis of infection, or when the patient presents difficult venipuncture, following the recommendations of the Guidelines for the Prevention of Intravascular Catheter-Related Infections ${ }^{(13)}$.

It can be seen in Table 2 that, $64 \%$ of the activities were in the NIC time, and the others, exceeded the referred time. This may have occurred because of the low frequency of activities during the study periods. Regarding the mean time of activities performed by nurses in direct and indirect care, studies by Westbrook et al. ${ }^{(4)}$ cite that the mean of times in percentages in indirect care ranges from $50 \%$ to $63 \%$. Indirect care consumes more time for nurses and is the most difficult to measure, since they can present concurrency during the working day. Therefore, the literature corroborates with the findings of this study, where the time spent in indirect care was $69 \%$.

In the online period, the records were made in the mobile device, at the edge of the bed, which allows a new reflection on the concepts of direct and indirect care, since mobile devices contribute to the accomplishment of activities and records in time resulting in a greater nurse/patient relationship and, consequently, the humanization of care. The study by Johansson $^{(14)}$ aimed to explore the experience of nursing students to use a Personal Digital Assistant PDA in clinical practice. It demonstrates that it has been found to be useful, increasing confidence and saving time, contributing to improving patient safety and quality of care.

The data in Table 3 indicate that nurses N3, N6 and N7 performed shifts of 12 hours, day and night, with the same shift time of 8.1 hours and $68 \%$ (\%WL). 12-hour shifts, because they 
represent extended time in nurses' work hours, may be indicative of a better distribution of their tasks, since in the shorter days, such as six hours, direct care activities and have to be repeated by another professional, because they are not aware of the patients on their scale, thus needing to perform some activities, such as "Physical examination" and/or "Patient visiting".

Nurses N1 and N5 performed daytime shifts of six hours, with the same shift time of 4.4 hours and $73 \%$ (\%WL). The N2 nurse performed only a six-hour shift during the observational period and had the highest shift time of $92 \%$. This effect is due to the professional not knowing the patients of the scale, being inferred that isolated shifts consume more professional time, increasing their WL. In addition, N2 nurses had the shortest experience among nurses, and this is another factor that should be considered.

In the on-line method, the N1 nurse presented the lowest WL, having performed six daytime shifts, whose shift time was 2.3 hours and $39 \%$ (\%WL). The distribution of activities between the morning and afternoon shifts should be equalized, in order to avoid overloading during daylight hours. On the other hand, the 12-hour daytime shift of $\mathrm{N} 1$ presents a shift time of 5.4 hours and $45 \%$ (\%WL).

When compared to the WL distribution of the nurses $\mathrm{N} 1$ and $\mathrm{N} 5$, it can be concluded that the designated activities, to be performed in the afternoon shift, are demanding a higher WL than those of the morning shift. In addition, the $\mathrm{N} 5$ professional performed a daytime shift of 12 hours, recording his shift time of 9.5 hours and $79 \%$ (\%WL). The N9 nurse performed only a night shift of 12 hours and presented a shift time of 9.8 hours and $81 \%(\% \mathrm{WL})$, pointing to the same effect occurred with $\mathrm{N} 2$, corresponding to an isolated shift with higher WL. Therefore, it should be considered that the isolated workplaces on a work scale overwhelm the professionals because they are unaware of the patients being assisted.

This factor should be taken into account when relief workers are reassigned to multiple units, replacing professionals at fixed scales because they cannot perform continuous care, overloading them and, consequently, bringing greater risks to patients. Another important finding relates to extended working hours (12-hour shifts), which indicated a better distribution of tasks and, consequently, lower WL, where no 12-hour shift overwhelmed the professional in this study except in isolated shifts.

Issues that should be considered are: the inexperience of professionals and the overload of work, as these can trigger occupational diseases, physical and emotional stress. The study by Dagget ${ }^{(15)}$ states that work-related stress varies according to the unit of work. The author presents the factors that elevate the stress of the nurses, being assistance to the chronic clinical patient, death and death, followed by uncertainty regarding the treatment of the patient contributing to the increase of WL.

The execution of multiple activities in a short period of time, as in isolated workplaces, can also overwhelm the professional, as the discontinuity in care impairs the nurse/patient relationship ${ }^{(2,16)}$.

In both periods of research, observational and online, the Perroca instrument ${ }^{(10)}$ and Cofen Resolution 293/04 ${ }^{(17)}$ were applied for the purposes of calculating DNP (Dimensioning of Nursing Personnel), based on the PCS (Patient Classification
System). The calculation pointed to the need of eight nurses to perform in the work scale in the observational period and nine nurses in the online period, in the 24 hours. However, only three nurses were scaled in the 24 hours during the study period, with three and four nurses missing, respectively, in the 24 hours, according to the Perroca scale and the Cofen Resolution ${ }^{(10,17)}$.

The Quality Sector database for the observational period describes that the nurses scaled in the 24 hours performed all the activities foreseen in their work shift. Therefore, the quantity indicated by Perroca's instrument ${ }^{(10)}$ would leave the staff oversized, representing a high cost.

The study by O'Brian-Pallas et al. ${ }^{(18)}$ recommends that the WL levels of the nursing team, calculated by the shift time, should be maintained at $85 \%$, with variations of $5 \%$. Levels above this value can represent a rise in costs and a decrease in the quality of care, an index below $80 \%$ indicates a greater probability of professional satisfaction and reduction of absenteeism. The shift working time refers to the productivity of the professional by the proportion of the time spent in the execution of the activities, exclusively related to the work. The time spent on the professional's personal needs, as well as rest periods, physiological needs, food, among others, was not considered in this study ${ }^{(3)}$.

On the other hand, considering the quantifiers provided by Perroca $^{(10)}$, could bring a high organizational cost without the counterpart of the balance of productivity of professionals. Proposals to measure WL are not related, in most institutions, to models and processes of care, as well as working conditions. The patient is classified as needing assistance, without considering the conditions that have to attend to it. This may seem to suggest that only the numerical number of professionals is insufficient to provide quality assistance, which could be reversed in improving working conditions, reverting to more agile and secure processes ${ }^{(19)}$.

The application of the online method to measure WL has proved to be an easy-to-use and accessible tool that can also be used in teaching. However, indirect care, which requires more dynamism in function due to the simultaneity of the tasks, can be difficult to record, such as short-term staff and/or family orientations and/or telephone service ${ }^{(20)}$. Although there are a large number of studies on the use of mobile devices in nursing, there are few formal studies on its application in bedside clinical practice. The computerization of documents in care processes requires nurses to adapt to changes in order to generate positive results in work processes and patients ${ }^{(11)}$.

The online method allowed generating managerial reports in real time. The synthetic report by patient chart, for example, visualized the time measured between the first and last care by a nurse. The other report generated recorded the work performed by the nurse. These two reports can be presented in real time and made available via web to managers and teachers, enabling the monitoring, evaluation and intervention regarding the team, through educational and/or corrective actions, translating into an assistance with higher quality and safety.

It is imperative to carry out new studies that promote the use of mobile devices with online resources in Inpatient Units, propitiating to measure the $\mathrm{WL}$, supporting managers/teachers in the qualification of care results, so that the nurse/student 
stays closer to the patient, generating greater recognition and professional satisfaction.

\section{Study limitations}

The study considers the reality of a pneumological hospital, therefore, the application of the tool must consider the reality of the service studied, according to the activities and profile of patients attended.

\section{Contributions to the nursing area}

The study compares observational and online methods, offering the possibility of computerization of workload management, accompanying activities performed in real time, assisting in decision making, seeking to guarantee the quality and safety of care of the professional and patient.

\section{CONCLUSION}

Both methods are used to measure $\mathrm{WL}$, and the activities are based on NIC. However, the online method developed through the use of software allows monitoring activities performed in real time, identifying work overloads and making possible the evaluation of performance by professional giving the management of the workload, allowing the execution and records of direct and indirect care in real time at the bedside.

\section{FUNDING}

This work was supported by the project titled Dimensioning of Nursing Personnel in Hospital Units financed by the edict MCTI/CNPq/Universal 14/2014.

\section{REFERENCES}

1. Panunto MR, Guirardello EB. Nursing workload in an intensive care unit of a teaching hospital. Acta Paul Enferm[Internet]. 2012[cited 2017 Apr 23];25(1):96-101. Available from: http://dx.doi.org/10.1590/S0103-21002012000100017

2. Schmoeller R, Trindade LL, Neis MB, Gelbcke FL, Pires DEP. Nursing workloads and working conditions: integrative review. Rev Gaúcha Enferm[Internet]. 2011[cited 2017 Apr 23];32(2):368-77. Available from: http://dx.doi.org/10.1590/S1983-14472011000200022

3. Fugulin FMT, Gaidinski RR. Dimensionamento da equipe de enfermagem em unidades de internação. In: Harada MJCS, (Org.). Gestão em Enfermagem: ferramenta para a prática segura. São Caetano do Sul, SP: Yendis; 2011. p. $214-22$.

4. Westbrook JI, Duffield C, Li L, Creswick NJ. How much time do nurses have for patients? a longitudinal study quantifying hospital nurses' patterns of task time distribution and interactions with health professionals. BMC Health Serv Res[Internet]. 2011[cited 2017 Apr 23];11:319. Available from: http://dx.doi.org/10.1186/1472-6963-11-319

5. Sordi LP. Dimensionamento dos Profissionais de Enfermagem: uma revisão da produção indexada na biblioteca virtual da saúde[Tese]. Serafina Correa: Escola de Administração/UFRGS - Universidade Aberta do Brasil-UAB; 2015.

6. Salehi A, Javanbakht M, Ezzatababdi MR. Stress and its determinants in a sample of Iranian nurses. Holist Nurs Pract[Internet]. 2014[cited 2017 Apr 23];28(5):323-8. Available from: http://dx.doi.org/10.1097/HNP.0000000000000043

7. Bulechek GM, Butcher HK, Dochterman JM. NIC: classificação das intervenções de enfermagem. 5. ed. Rio de Janeiro: Elsevier; 2010.

8. Doran D, Haynes BR, Estabrooks CA, Kushniruk A, Dubrowski A, Bajnok I, et al. The role of organizational context and individual nurse characteristics in explaining variation in use of information technologies in evidence based practice. Implement Sci[Internet]. 2012[cited 2017 Apr 23];7:122. Available from: http://dx.doi.org/10.1186/1748-5908-7-122

9. Levitt D, List JA. Was there really a hawthorne effect at the hawthorne plant? an analysis of the original illumination experiments. Am Econ J Appl Econ[Internet]. 2011 [cited 2017 Apr 23];3(1):224-38. Available from: http://www.aeaweb.org/articles.php?doi = 10.1257/ app.3.1.224

10. Perroca MG. The new version of a patient classification instrument: assessment of psychometrics properties. J Adv Nurs[Internet]. 2012[cited 2017 Apr 23];69(8):1862-8. Available from: http://onlinelibrary.wiley.com/doi/10.1111/jan.12038/pdf

11. Moreno FN, Haddad MCL, Vannuchi MTO, Jenal S, Girotti SKOG. Measuring nurses' work hours in a philanthropic tertiary hospital. Cogitare Enferm[Internet]. 2014[cited 2017 Apr 23];17(1):50-622. Available from: http://www.redalyc.org/articulo. oa?id $=483648962007$

12. Severino R, Saiote E, Martinez AP, Deodato S, Nunes L. Nursing activities score: índice de avaliação da carga de trabalho de enfermagem na UCl. Rev Perc[Internet]. 2010[cited 2017 Apr 23];16:3-13. Available from: http://hdl.handle.net/10400.26/9208

13. Guidelines for the Prevention of Intravascular Catheter-Related Infections[Internet]. 2011[cited 2017 Apr 23]. Available from: http:// www.cdc.gov/hicpac/pdf/guidelines/bsi-guidelines-2011.pdf

14. Johansson PE, Peterson GI, Nilsson GC. Nursing students' experience of using a personal digital assistant (PDA) in clinical practice: an intervention study. Nurs Educ Today[Internet]. 2012[cited 2017 Apr 23];33(10):1246-51. Available from: http://dx.doi. org/10.1016/j.nedt.2012.08.019

15. Dagget T, Molla A, Belachew T. Job related stress among nurses working in Jimma Zone public hospitals, South West Ethiopia: a cross sectional study. BMC Nurs[Internet]. 2016[cited 2017 Apr 23];15:39. Available from: http://dx.doi.org/10.1186/s12912-016-0158-2

16. Wang S, Liu Y, Wang L. Nurse burnout: Personal and environmental factors as predictors. Int J Nurs Pract[Internet]. 2015[cited 
2017 Apr 23];21(1):78-86. Available from: http://dx.doi.org/10.1111/ijn.12216

17. Conselho Federal de Enfermagem - COFEN. Resolução n 293, de 21 de setembro de 2004. Fixa e Estabelece Parâmetros para o Dimensionamento do Quadro de Profissionais de Enfermagem nas Unidades Assistenciais das Instituições de Saúde e Assemelhados. Rio de Janeiro: Cofen; 2004.

18. O’Brien-Pallas L, Thomson D, Hall LM, Ping G, Kerr M, Wang S. Evidence-based standards for measuring nurse staffing and performance[Internet]. Otawa, Ontario: Canadian Health Services Research Foundation; 2004[cited 2017 Apr 23]. Available from: http://www.cfhi-fcass.ca/SearchResultsNews/04-09-01/661fa44b-eb53-4717-96b7-a9ac4054f99c.aspx

19. Neis MEB, Gelbcke FL. Workload in nursing work: variable dimensioning of nursing staff. Enferm Foco[Internet]. 2011 [cited 2017 Apr 23];2(1):6-9. Available from: http://revista.portalcofen.gov.br/index.php/enfermagem/article/view/65

20. Sanchez-Garcia AB, Lopez-Montesinos MJ, Fernandez-Aleman JL. Wireless devices in nursing education. Invest Educ Enferm[Internet]. 2013[cited 2017 Apr 23];31(1):95-106. Available from: http://www.scielo.org.co/pdf/iee/v31n1/v31n1a12.pdf 